\title{
Karakteristik pelayanan prima
}

\section{Pokok Pembahasan}

Karakteristik pelayanan prima.

\section{Tujuan Pembelajaran}

Agar Mahasiswa dapat memahami karakteristik pelayanan prima.

\section{Konteks dan Isi Pembelajaran}

\section{a. Pengertian karakteristik}

Pengertian karakter menurut para ahli;

1. Maxwell

Menurutnya, karakter jauh lebih baik dari sekedar perkataan. Lebih dari itu, karakter merupakan sebuah pilihan yang menentukan tingkat kesuksesan.

2. Wyne

Menurut wyne, karakter menandai bagaimana cara ataupun teknis untuk memfokuskan kepada penerapan nilai kebaikan kedalam tindakan ataupun tingkah laku.

3. Kamisa

Pengertian karakter ialah sifat-sifat kejiwaan, akhlaq, dan budi pekerti yang dapat membuat seseorang terlihat beda dari orang lain. Berkarakter dapat di artikan juga sebagai memiliki watak dan juga berkepribadian.

4. Doni kusuma

Pengertian karakteristik, merupakan ciri, gaya, sifat, atau pun karakteristik diri seseorang yang berasal dari bentukan atau pun tempaan yang didapatkan dari lingkungannya.

5. W.B. saunders

Karakter merupakan sifat nyata dan berbeda yang ditunjukan oleh individu. Karakter dapat dilihat dari berbagai macam atribut yang aada dalam pola tingkah laku.

6. Gulo. W

Menurut Gulo W. Pengertian karakter ialah kepribadian yang dilihat dari titik tolak etis ataupun moral. Biasanya karakter 
memlikihubungan dengan sifat-sifat yang relatif tetap.

7. Alwisol

la berpendapat bahwa penggambaran tingkah laku yang dilaksanakan dengan menonjolkan nilai secara implisit atau eksplisit.

\section{b. Pengertian pelayanan prima}

Secara etimologi, pelayanan bisa diartikan sebagai usaha melayani orang lain. Pada dasarnya pelayanan prima adalah melakukan pelayanan sebaik mungkin kepada para pelanggan, sehingga pelanggan menjadi merasa puas. Pelayanan prima dapat menimbulkan feedback yang baik, tak hanya kepada pelanggan saja tetapi bagi yang memberikan pelayanan tersebut. Pelayanan prima menurut para ahli :

1. Menurut Moenir

Pelayanan prima yaitu proses pemenuhan kebutuhan melalui aktivitas secara langsung

2. Menurut Kotler

Yaitu suatu tindakan (memberikan pelayanan) yang akan diberikan kepada seseorang.

3. Menurut suparlan

Pelayanan prima adalah pemberian pertolongan kepada orang lain. Pertolongan tersebut yaitu berupa materi maupun non materi yang nantinya bisa mengatasi masalahnya sendiri (klien/pelanggan)

4. Menurut Hadipranata

Yaitu aktivitas diluar pekerjaan pokok yang diberikan kepada pelanggan dan bisa dirasakan sebagai penghargaan atau penghormatan.

c. Karakteristik pelayanan prima

1. Penampilan

Penampilan sangat di perlukan untuk melakukan pelayan prima kepada para pelanggan, karena dengan penampilan yang baik dapat meyakinkan pelanggan saat memberikan pelayanan. 
Misalnya sebagai resepsionis maka harus memiliki tutur kata yang baik, berpenampilan yang menarik, memiliki tubuh yang porposional, dan lain-lain.

\section{Kesopanan Dan Ramah}

Pegawai yang melayani masyarakat atau pelanggan maka memerlukan sikap sopan-santun, sabar, dan tidak egois karena masyarakat pengguna jasa pelayanan berasal dari berbagai kalangan baik dari perbedaan tingkat ekonomi maupun tingkat status sosial.

3. Kesediaan Melayani

Pegawai harus profesional atau harus benar-benar dalam melayani pelanggannya, sebagaimana tugasnya yang harus siap selalu melayani pelanggan yang memang memerlukannya.

4. Pengetahuan Dan Keahlian

Supaya dapat melayani dengan baik, maka pegawai harus memiliki pengetahuan dan keahlian dalam bidang yang dikerjakannya.

Misalnya petugas pelayanan yang memiliki tingkat pendidikan atau pelatihan tertentu maka jabatannya-pun harus yang sesuai dengan keahliannya.

5. Tepat Waktu Dan Janji

Dalam pelayanan maka pegawai dalam melakukan tugasnya jika membuat janji dengan pelanggan harus di perhitungan terlebih dahulu, apakah waktu dan janji tersebut bisa di tepati, misalnya mengadakan pertemuan dengan pelanggan dalam waktu kurun waktu 3 hari maka harus dapat terpenuhi.

6. Kejujuran Dan Kepercayaan

Dalam melakukan pelayanan harus memiliki aspek kejujuran dalam segala hal, baik itu jujur dalam bentuk aturan, jujur dalam bentuk pembiayaan dan jujur dalam menyelesaikan pekerjaan tepat pada 
waktunya. Jika bersikap jujur maka petugas pelayanan dapat di percaya dari berbagai aspek misalnya dari segi perkataannya, sikapnya, dalam melakukan bekerja, dan lain-lain.

\section{Efesien}

Pelayanan kepada masyarakat atau pelanggan harus efesien dan efektif, karena pelanggan menuntut hal-hal tersebut. Sehingga dapat menghasilkan biaya murah, waktu singkat dan tepat, serta hasil dari pelayanan yang berkualitas. Oleh karena itu efesien dan efektif merupakan hal yang harus di wujudkan dan harus menjadi perhatian serius dalam melakukan pelayanan.

8. Kepastian Hukum

Jika hasil dari pelayanan yang dilakukan kepada pelanggan berupa suatu keputusan, maka harus memiliki kepastian hukum. Jika tidak memiliki kepastian hukum yang jelas maka akan berpengaruh kepada sikap masyarakat, misalnya dalam pelayanan mengurus surat-surat berharga jika ditemukan ketidakpastian hukum maka akan berpengaruh kepada kredibilitas perusahaan atau pelayanan tersebut.

9. Keterbukaan

Setiap urusan atau kegiatan yang memperlakukan ijin, maka keterbukaan perlu di lakukan. Sikap keterbukaan itu akan berpengaruh pada kejelasan informasi kepada masyarakat atau pelanggan.

10. Biaya

Dalam pelayanan maka perlunya penentuan pembiayaan yang wajar. Oleh karena itu biaya harus disesuaikan dengan daya beli masyarakat, harus transparan, dan sesuai peraturan.

11. Tidak Rasial

Dalam melakukan pelayanan tidak boleh membeda-bedakan ras, suku, agama dan politik, jadi harus melayani secara merata. 
12. Kesederhanaan

Prosedur atau tata cara pelayanan kepada para pelanggan harus dipermudah dan tidak berbelit-belit dalam pelaksanaannya.

Pilihan ganda

1. Karakter menandai bagaimana cara ataupun teknis untuk memfokuskan kepada penerapan nilai kebaikan kedalam tindakan ataupun tingkah laku. Pernyataan di atas merupakan pengertian karakter menurut ...
a. Maxwell
b. Wyne
c. Doni kusuma
d. Kamisa

2. Karakteristik, merupakan ciri, gaya, sifat, atau pun karakteristik diri seseorang yang berasal dari bentukan atau pun tempaan yang didapatkan dari lingkungannya.

Pernyataan di atas merupakan pengertian karakter menurut ...
a. Maxwell
b. Wyne
c. Doni kusuma
d. Kamisa

3. Siapakah yang memiliki persamaan dalam pendapatnya mengenai karakteristik?
a. maxwell \& wyne
b. doni \& kusuma
c. doni kusuma \& kamisa
d. kamisa \& W. B. Saunders

4. Pelayanan prima yaitu proses pemenuhan kebutuhan melalui aktivitas secara langsung.

Pendapat tersebut tentang pelayanan prima yang dikemukakan oleh ... 

a. Moenir
b. Kotler
c. Suparlan
d. Hadipranata

5. Pemberian pertolongan kepada orang lain. Pertolongan tersebut yaitu berupa materi maupun non materi yang nantinya bisa mengatasi masalahnya sendiri (klien/pelanggan)

Pendapat tersebut di kemukakan oleh ...
a. Moenir
b. Kotler
c. Suparlan
d. Hadipranata

6. Aktivitas diluar pekerjaan pokok yang diberikan kepada pelanggan dan bisa dirasakan sebagai penghargaan atau penghormatan.

Pendapat tersebut di kemukakan oleh ...
a. Hadipranata
b. Kotler
c. Moenir
d. Suparlan

7. Yang bukan termasuk karakteristik pelayanan prima adalah ...
a. Tidak Rasial
b. Biaya
c. Keterbukaan
d. semua jawaban salah

8 . "Pelayanan mengurus surat-surat berharga jika ditemukan ketidakpastian hukum maka akan berpengaruh kepada kredibilitas perusahaan atau pelayanan tersebut"

Studi kasus diatas memaparkan karakteristik tentang ...
a. Kejujuran Dan Kepercayaan
b. Efesien
c. Kepastian Hukum
d. Keterbukaan

9. Suatu tindakan (memberikan pelayanan) yang akan diberikan kepada seseorang. 
Pendapat diatas dikemukakan oleh ...
a. Moenir
b. Suparlan
c. Hadipranata
d. Kotler

10. Mengadakan pertemuan dengan pelanggan dalam waktu kurun waktu 3 hari maka harus dapat terpenuhi.

Pernyataan diatas ini merupakan contoh dari karakteristik ...
a. Kepastian Hukum
b. Keterbukaan
c. Kejujuran Dan Kepercayaan
d. Efesien

\section{ESSAY}

1. Jelaskan pengertian pelayanan prima menurut anda!

2. Jelaskan pengertian pelayanan prima secara etimologi?

3. jelaskan pengertian karakteristik menurut Kamisa!

4. Jelaskan pengertian karakteristik menurut anda!

5. sebutkan dan jelaskan 5 karakteristik kualitas pelayanan prima!

\section{JAWABAN}

Pilihan ganda

1. $b$

2. $\mathrm{C}$

3. c

4. a

5. C

6. a

7. d

8. $\mathrm{C}$

9. d

10. $\mathrm{c}$

\section{Essay}

1. Kebijaksanaan dosen 
2. Pelayanan diartikan sebagai usaha melayani orang lain yang dapat menimbulkan feedback yang baik.

3. Pengertian karakter ialah sifat-sifat kejiwaan, akhlaq, dan budi pekerti yang dapat membuat seseorang terlihat beda dari orang lain. Berkarakter dapat di artikan juga sebagai memiliki watak dan juga berkepribadian.

4. Kebijaksanaan dosen

5. 1. Penampilan

Penampilan sangat di perlukan untuk melakukan pelayan prima kepada para pelanggan, karena dengan penampilan yang baik dapat meyakinkan pelanggan saat memberikan pelayanan

2. Kesopanan Dan Ramah

Pegawai yang melayani masyarakat atau pelanggan maka memerlukan sikap sopan-santun, sabar, dan tidak egois karena masyarakat pengguna jasa pelayanan berasal dari berbagai kalangan baik dari perbedaan tingkat ekonomi maupun tingkat status sosial.

3. Kesediaan Melayani

Pegawai harus profesional atau harus benar-benar dalam melayani pelanggannya, sebagaimana tugasnya yang harus siap selalu melayani pelanggan yang memang memerlukannya.

\section{Pengetahuan Dan Keahlian}

Supaya dapat melayani dengan baik, maka pegawai harus memiliki pengetahuan dan keahlian dalam bidang yang dikerjakannya.

5. Tepat Waktu Dan Janji

Dalam pelayanan maka pegawai dalam melakukan tugasnya jika membuat janji dengan pelanggan harus di perhitungan terlebih dahulu, 


$$
\text { Daftar Pustaka }
$$

Wahyu B.S, Nurhasanah. Jurnal Pendas Mahakam. Vol 3 (2). 151-158. Agustus 2018 Prosiding Seminar Nasional STKIP Muhammadiyah Bogor Tahun 2015 VOL. 1 No. 1. ISSN: 9772-443-2701-4.

Jurnal IImiah Edutecno. Volume 19. No. 1. Tahun 2019. ISSN: 2302-2825

Wijaya, E. Yuhana, 1999, Pelayanan Prima, Penerbit Armico Bandung 